\title{
Drago Kunej
}

Glasbenonarodopisni inštitut, Znanstvenoraziskovalni center Slovenske akademije znanosti in umetnosti in Filozofska fakulteta, Univerza v Ljubljani

Institute of Ethnomusicology, Research Centre of the Slovenian Academy of Sciences and Arts and Faculty of Arts, University of Ljubljana

\section{Rebeka Kunej}

Glasbenonarodopisni inštitut, Znanstvenoraziskovalni center

Slovenske akademije znanosti in umetnosti

Institute of Ethnomusicology, Research Centre of the Slovenian Academy of Sciences and Arts

\section{Dancing For Ethnic Roots: Folk Dance Ensembles of Ethnic Minority Groups in Slovenia* Plesanje za etnične korenine: folklorne
skupine etničnih manjšin v Slovenijiit}

Prejeto: 3. avgust 2019

Sprejeto: 26. avgust 2019

Ključne besede: etnoidentitetni plesi, folklorna skupina, folklorna umetnost, diaspora, migracije

\section{IZVLEČEK}

Folklorne skupine v okviru manjšinskih etničnih skupnosti (albanske, bošnjaške, črnogorske, hrvaške, makedonske in srbske) so v Sloveniji nastale v 90. letih 20. stoletja, po razpadu Jugoslavije. Avtorja pokažeta ključne razloge $\mathrm{v}$ delovanju folklorne de-
Received: $3^{\text {rd }}$ August 2019

Accepted: 26 ${ }^{\text {th }}$ August 2019

Keywords: ethno-identity dance, folk dance ensembles, folkloristic art, diaspora, migrations

\section{ABSTRACT}

Folk dance ensembles within minority ethnic communities (Albanian, Bosniak, Montenegrin, Croatian, Macedonian and Serbian) in Slovenia were formed in the 1990s, after the breakup of Yugoslavia. The authors present the key reasons for the folklore

* The article was written in frame of the research programme Research on Slovenian Folk Culture in Folklore Studies and Ethnology, No. P6-0111, and the research project Music and Ethnic Minorities: (Trans)cultural Dynamics in Slovenia After the Year 1991, No. J6-8261, funded by the Slovenian Research Agency.

** Članek je nastal v okviru raziskovalnega programa Folkloristične in etnološke raziskave slovenske ljudske duhovne kulture (P6-0111) in raziskovalnega projekta Glasba in etnične manjšine: (trans)kulturne dinamike v Sloveniji po letu 1991 (J6-8261), ki ga je finančno podprla Javna agencija za raziskovalno dejavnost Republike Slovenije. 
javnosti, ki je vplivala na nastanek t. i. manjšinskih folklornih skupin, kakšni so bili začetki delovanja ter kako so se sčasoma organizirale, institucionalizirale in vključile v sistem delovanja ljubiteljske kulture v Sloveniji. Manjšinskim folklornim skupinam je cilj izkazovanje etnične pripadnosti skozi ples, a hkrati tudi želja po obogatitvi prostora v novi državi in integraciji v družbo, v kateri živijo. activities that contributed to the emergence of the so-called minority folk dance ensembles, describe their beginnings and how they eventually became organized, institutionalized, and integrated into the amateur culture system in Slovenia. The goal of minority folk dance ensembles is to dance for ethnic roots, but at the same time, the desire to enrich the cultural space in their new county and to integrate into society in which they live.

Folk dance ensembles are a form of cultural production with over a century old tradition in Slovenia. The history and development of the folk dance ensembles, which - aside from few specifics - is not significantly different from the history of other folk dance ensembles in this part of Europe, has been discussed in various works. ${ }^{1}$ In this paper, we want to investigate the emergence of folk dance ensembles within minority ethnic communities in the 1990s, which were not present in Slovenia before.

Activities, purpose and stage production of folk dance ensembles have recently been the topic of various folkloristic and ethnological discussions addressed by the authors to such practices in Southeastern and Eastern Europe, with a particular focus on the second part of the $20^{\text {th }}$ century and their function in the totalitarian and socialist societies. ${ }^{2}$ The authors mainly focus on the activities of folklore ensembles in their countries of origin, as well as on their activities in diasporic communities. ${ }^{3}$ Only in exceptional cases,${ }^{4}$ the authors have also been focusing on the minority communities within their

1 E.g. Rebeka Kunej, "Leaders and Followers: Artistic Leaderships and Stage Presentations of Folk Dances in a Slovenian Folklore Ensemble," in Folklore Revival Movements in Europe Post 1950: Shifting Contexts and Perspectives, eds. Daniela Stav lová, and Theresa Jill Buckland (Prague: Institute of Ethnology of the Czech Academy of Sciences, 2018), 25-271; Rebeka Kunej, "From Kolo to Polka: Folk Dance Ensembles in Slovenia after 1991," in Music and Dance of the Slavic World: Tradition and Transitions, eds. Sonja Zdravkova Djeparoska (Skopje: Faculty of Music, forthcoming).

2 E.g. Philipp Herzog, "National in Form and Socialist in Content" or Rather "Socialist in Form and National in Content"?: The "Amateur Art System" and the Cultivation of "Folk Art" in Soviet Estonia," Narodna Umjetnost 47, no. 1 (2010): 115-40; Anna Ilieva, "Bulgarian Folk Dance during the Socialist Era, 1944-1989," Yearbook for Traditional Music 33 (2001): 123-26; Sille Kapper, "Post-Colonial Folk Dancing: Reflections on the Impact of Stage Folk Dance Style on Traditional Folk Dance Variation in Soviet and Post-Soviet Estonia," Journal of Baltic Studies 47, no. 1 (2016): 93-111; Martina Pavlicová and Lucie Uhlíková, "Folklore Movement and Its Function in the Totalitarian Society (on an Example of the Czech Republic in the 2nd Half of the $20^{\text {th }}$ Century)," Národopisná Revue 23 (2013), no. 5 (2013): 31-41; Filip Petkovski, "Professional Folk Dance Ensembles in Eastern Europe and the Presentation of Folk Dance on Stage," in Music and Dance in Southern Europe: New Scopes of Research and Action. Fourth Symposium of the ICTM Study Group on Music and Dance in Southeastern Europe, (Belgrade: ICTM Study Group on Music and Dance in Southeastern Europe; Faculty of Music, University of Belgrade, 2016), 173-78; Daniela Stavĕlová and Theresa J. Buckland eds., Folklore Revival Movements in Europe Post 1950: Shifting Contexts and Perspectives (Prague: Institute of Ethnology of the Czech Academy of Sciences, 2018).

3 E.g. Rebeka Kunej and Drago Kunej, "Folklorna skupina v diaspori. Soočanje tradicije in ustvarjalnosti v Ameriki," Etnolog 26 (2016): 49-64; Iivi Zájedová and Eha Rüütel, "National Cultural Hobby Activities of Estonians in Exile and Their Role as a Means of Perserving Estonianism," Ethnologia Actualis Slovaca 9 (2009): 97-109; Iivi Zájedová and Eha Rüütel, "Folk Dance Practice and Transmission of the Folk Dance Tradition by Expatriate Estonians in Sweden and Germany," Česky Lid 101, no. 1 (2014): 57-76.

4 E.g. Alma Bejtullahu, "Glasba in ples narodnih manjšin v Sloveniji: Nacionalna identiteta, eksotika, past stroke," Traditiones 45, no. 2 (2016): 159-76. 
own state, ${ }^{5}$ due to their understanding of folk dance ensembles as the apparatus of the state, which was used to portray the nations as strong, pure entities. As Laurent Auber noted, the tradition of dancing in the form of folk dance ensembles was exploited for "national cohesion". ${ }^{6}$ At the same time, contemporary discussions ${ }^{7}$ increasingly note that in their activities, folk dance ensembles avoided the dance heritage which in some way represented a departure from the image of a "pure" nation.

The article focuses on those minority folk dance ensembles that have emerged in Slovenia only after the breakup of Yugoslavia (Albanian, Bosniak, Montenegrin, Croatian, Macedonian and Serbian folk dance ensembles), and omits folk dance ensembles operating within constitutional minorities (i.e. the Italian and the Hungarian National Communities and a special Roma Community).

The authors base their case on their own experience, having participated in different folk dance ensembles in the 1980s and 1990s and witnessed a programme turn (see more below) following the breakup of Yugoslavia. Later on, we have replaced the autobiographical method with observation of and participation in various events featuring folk dance ensembles. In terms of data, we rely heavily on publications in Folklornik magazine ${ }^{8}$ and make use of digital ethnography. We have gained additional insight from interviews with stakeholders, conducted since 2017 as part of the research project Music and Ethnic Minorities: (Trans)cultural Dynamics in Slovenia After the Year 1991. The interviews were held with artistic leaders of individual minority folk dance ensembles and/or with those who were also part of the institutional guidance of such ensembles.

The article first presents an insight into the history of folk dance ensembles in Slovenia, and at the same time, into the modern-day organization of the folklore activity in Slovenia. This is followed by a description of the situation in 1991 and an analysis of the circumstances that contributed to the emergence of minority folk dance ensembles in Slovenia at the turn of the $21^{\text {st }}$ century. In doing so, the authors want to highlight the key moments in the amateur cultural activities that led to the founding of ethnic minority folk dance ensembles, and use them to answer questions such as why minority folk dance ensembles appeared only in the 90s, what were the beginnings of these ensembles, and how they eventually became organized, institutionalized, and integrated into the system of amateur culture in Slovenia.

5 For example, this is different for American and Australian researchers, who are more likely to study minority communities in relation to dance in their own countries, e.g. Jeanette Mollenhauer, "Dance in Diaspora: The Politics of Practice", Paper presented at Power, Politics and the Dancing Body; Dance Research Forum Ireland Conference, Limerick, June 2018: 1-8; Jeanette Mollenhauer, "Dancing Transnationally: Croatian Immigrants in Sydney, Australia," Narodna umjetnost 561 (2019): 129-47; Sau-ling C. Wong, "Dancing in the Diaspora: Cultural Long-Distance Nationalism and the Staging of Chineseness by San Francisco's Chinese Folk Dance Association," Journal of Transnational American Studies 2, no. 1 (2010): Article 15, http://escholarship.org/uc/item/50k6k78p; Louise Wrazen, "Diasporic Experiences: Mediating Time, Memory and Identity in Górale Performance," Musicultures 32 (2005): 34-51.

6 Laurent Aubert, The Music of the Other: New Challenges for Ethnomusicology in a Global Age, trans. Carla Ribeiro (Aldershot, England; Burlington, VT: Ashgate, 2007), 50.

7 Cf. Pavlicová and Uhlíková, "Folklore Movement and Its Function in the Totalitarian Society (on an Example of the Czech Republic in the 2 nd Half of the $20^{\text {th }}$ Century)," 38.

8 Folklornik is a professional magazine for re-creators of folk tradition, published by the Public Fund for Cultural Activities of the Republic of Slovenia since 2015, and is primarily intended for folk dance ensembles, folk singers and folk musicians, as well as anyone else working with heritage (clothing, customs and traditions, etc.). 


\section{Ethno-identity dance and minority folk dance ensembles}

Folk dance ensembles can theoretically be classified into the concept of ethno-identity dance used by Anthony Shay. ${ }^{9}$ By using this concept and expression, Shay wanted to avoid redefining the terms folk, ethnic, or vernacular dance, and therefore suggested using single terminology to describe and analyse "the genre of staged and presentational traditional, folk, and popular dance". ${ }^{10}$ In his view, the term incorporates "all attempts to display some kind of ethnic identity through dance representation", ${ }^{11}$ which can be found in festive or concert settings, tourist contexts, and competitions, which belongs to a huge spectrum of staged traditional or folk dances as a separate genre. He points to various motives that encourage individuals to participate in dance events, either as a performer or viewers (audience), while highlighting and addressing three key ones in his book: sex, profit and nation. An important aspect of ethno-identity dance genres is that they are primarily being used for the purposes of representation and self-presentations, and invariably refer to some form of dance that is associated with specific ethnic identities. $^{12}$

The activities of folk dance ensembles and their stage production perfectly match the proposed term. Therefore, we understand the dance genre, along with related activities by individuals, groups and institutions discussed in the article, in the concept of ethno-identity dance. As pointed out by Shaw, this avoids using a term such as "folk dance", which is oversaturated, among public and in academia, and without implying what is "less than" or "not as authentic" as other dance genres. ${ }^{13}$

Folk dance ensembles fall within the broader framework of "folklore activity", which includes tradition-based music, dance, clothing culture, and customs and rituals, and is often the most popular, active and representative activity of minority cultural societies in Slovenia. Often, folklore activity is most fully embraced in folk dance ensembles that bring together and integrate these elements of tradition. Members of minority communities have repeatedly point out the great importance of folk dance ensembles in "maintaining and building their national identity"; ${ }^{14}$ in part because the presentation of one's tradition to others, especially in the form of stage performances, is one of the most important goals of folk dance ensembles. ${ }^{15}$

Although all folk dance ensembles operating in Slovenia can be defined as Slovenian, we hereafter distinguish folk dance ensembles that present dances based on the tradition of Slovenes from those of other ethnic groups, using the term Slovenian exclusively for them. When the term minority folk dance ensemble is used, it refers to those ensembles in Slovenia whose activities are based on the dance traditions of ethnic/national groups of the former Yugoslavia; that is, folk dance ensembles of the so-called new national

Anthony Shay, Ethno Identity Dance for Sex, Fun and Profit: Staging Popular Dances around the World (London: Palgrave Macmillan, 2016).

10 Ibid., viii.

11 Ibid., 14

12 Ibid., 6.

13 Ibid., 10 .

14 Milan Glamočanin, "Organiziranje pripadnikov srbske skupnosti v kulturna društva v Sloveniji," Folklornik 6 (2010): 127.

15 Cf. Bojan Knific, "Interpretiranje plesnega izročila: Lokalno, nacionalno in nadnacionalno," Traditiones 42, no. 1 (2013): 133. 
communities. Similar to Slovenian ones today, minority groups are monocultural in their representations, usually representing only the programme (culture) of their own ethnic community.

\section{Activities of folk dance ensembles in Slovenia and professional guidance of folklore activity}

Today, folk dance ensembles in Slovenia are all institutionally organized. They operate as sections within cultural societies or as independent (folk) societies, and are non-profit entities whose activities are often made possible through financing of amateur cultural activities from state and local sources, as well as through symbolic membership fees. The greatest responsibility in terms of the extent to which these activities are supported seems to lie with local communities.

The beginnings of folk dance ensembles in Slovenia - dating back to the first half of the $20^{\text {th }}$ century - are related to the presentation of dance traditions that were for the most part still practiced. At the time, it was primarily an experience of dance tradition for the performers. Even with the rise of the folk dance ensembles after World War II, the division between original (presenting their living dance tradition) and performing ensembles (which presented newly learned dance repertoire). ${ }^{16}$ Today, such a division no longer makes sense, because members of folk dance ensembles no longer share the dance experience they present on stage in terms of vival dance, as defined by Nahachewsky ${ }^{17}$ - today, their shared experience is performing - recreating folk dance on stage and public presentations of ethno-identity dances. An increasing number of authors ${ }^{18}$ have recently pointed to this, and in Slovenia, it is true for both minority and Slovenian folk dance ensembles. What Wrazen noted for younger members of the Polish Gorals in Toronto - "through performance, [they] may portray a near-mythical world of the past, imagined, possibly longed for, but not actually remembered"19 - also applies to ensembles in Slovenia.

Rather than the performers' own dance experiences, the source of their performances are publications, archives, dance classes (seminars) or ready-made stage choreographies, on the basis of which a choreographer creates a stage performance. For most of the participants today, folk dance ensembles represent a leisure activity per se, the possibility for social interactions and regular socializing, and last but not least, the fulfillment of personal ambitions with regard to public speaking.

Folk dance ensembles were (and still are) a part of cultural policy. Especially in the former communist countries, folk dance ensembles were a means of mass education and consolidation of national cohesion: "For the governmental powers concerned, the perversion, codification and mediatization of musical and choreographic folkloric forms

16 More in: Kunej, "From Kolo to Polka".

17 Andriy Nahachewsky, Ukrainian Dance: A Cross-Cultural Approach (Jefferson, N.C: McFarland \& Co, 2012), 24-8.

18 Bejtullahu, "Glasba in ples narodnih manjšin v Sloveniji"; Kunej, "From Kolo to Polka"; Shay, Ethno Identity Dance for Sex, Fun and Profit; Wrazen, "Diasporic Experiences".

19 Wrazen, "Diasporic Experiences," 48. 
of often ritual origin constituted ideal instruments of propaganda and normalization". ${ }^{20}$ Their purpose was to eradicate certain practices and beliefs, and to present them as completely separate from the actual context.

In Slovenia, the number of newly-established folk dance ensembles increased after World War II, within the framework of cultural and educational societies. The first decade saw the emergence of folk ensembles that operated within trade unions or as independent educational associations. The influence of trade unions on the functioning of societies began to diminish in the 1960s, and cultural societies began to gain independence. This change was also reflected in their names: the adjectives educational and union became increasingly less frequent and were being replaced by cultural.

Folk dance ensembles have always been an important pillar of such educationalcultural-amateur activities. Their activities have always been watched over by cultural politics or a relevant institution. The name of these institutions has often been changed, but their mission remained more or less the same. After World War II, amateur cultural activities were at first covered by Ljudska prosveta Slovenije ("People's Education of Slovenia"), which had been established on the basis of the programme guidelines of the Liberation Front and later adopted the conceptual framework of the Communist Party of Slovenia. In the 1950s, more and more educational associations were formed within trade unions, which led to the formation of Zveza Svobod in prosvetnih društev Slovenije ("Union of Freedoms and Educational Societies of Slovenia"). In the 1960s, the organization has been renamed to Zveza kulturno-prosvetnih organizacij Slovenije ("Association of Cultural and Educational Organizations of Slovenia"), and in the 1970s, to Zveza kulturnih organizacij Slovenije ("Association of Cultural Organizations of Slovenia") or ZKOS. In the 1990s, ZKOS was faced with an unregulated status and a broken system of financing. The year 1996 saw the establishment of the Sklad republike Slovenije za ljubiteljske kulturne dejavnosti (Fund of the Republic of Slovenia for Amateur Cultural Activities) or SLKD, which provided professional assistance for amateur cultural activities and co-financed programmes of more than local importance. The tendency of this institution to emphasize expertise and professionalism is also reflected in its renaming to the Javni sklad Republike Slovenije za kulturne dejavnosti (Public Fund for Cultural Activities of the Republic of Slovenia) or JSKD in 2010.

The political-financial role of the above institutions was only later joined by the function of professional facilitator. The first professional in the field of folklore activities at the then ZKOS was employed in 1984, and the institution (or its successors) retained this position ever since. The activities of the ensembles were also guided by professional working bodies, which included external members and decided on the co-financing of the ensembles, as well as on the design of the educational program.

Also organized within this institution were annual meetings of folk dance ensembles. Until 1990s, they consisted of demonstration (exhibition) programme and were essentially non-competitive. The meetings were held at the local, regional and national ${ }^{21}$ levels. Ensembles were selected at each level, which then presented their programme on a higher level. In the past, the ensembles were not only selected based on the quality

20 Aubert, The Music of the Other, 50.

21 During the Yugoslav period, the meetings were only held at republican level, i.e. in Slovenia. There was never an official national level for the entire Yugoslavia. 
of the presented programme, but also on the progress made since the previous year, and partly dependent on the programme concept of the higher-level event, in order to ensure the diversity of selected participants. After each meeting, there was a discussion with an expert evaluator who gave his assessment of each performance and provided some guidance, encouragement and commendation to each participating ensemble.

The current three-tier selection system for the meetings has a competitive/evaluative nature and is therefore often referred to as "competition". The expert evaluator (often an experienced artistic leader of another folk dance ensemble, their formal education being irrelevant) assesses the performance of each ensemble according to certain criteria, evaluates it with points, and makes the selection for the higher level event based on the total scores. Regional meetings include two expert evaluators (for music and for dance) who select ensembles for the national level. Promotion to higher levels of events represents an important (if not key) reference for various tenders for co-financing programmes and activities of the ensembles.

\section{Slovenian ensembles and Yugoslav programme}

Larger (amateur) folk dance ensembles and professional national folk dance ensembles ${ }^{22}$ in all the republics of the former Yugoslavia had a programme that was not limited to individual republics but to the entire Yugoslavia. The members of Slovenian folk dance ensembles coined the term Yugoslav programme, also Southern programme, Slovenia being the northernmost republic of the country. The term was used to colloquially refer to all those parts of the programme that were not linked to the Slovenian tradition. In this way, the folk dance ensembles as cultural institutions acted in a political manner, using their programme orientation to support political slogan of brotherhood and unity among the nationalities in Yugoslavia.

There is no information about Slovenian folk dance ensembles presenting the dance traditions of the other nationalities of Yugoslavia before World War II, when Slovenes were already part of the common Kingdom of Yugoslavia. However, historical archives show that this changed after 1945 . For example, as evidenced by a leaflet ${ }^{23}$ for the folk dance "competition" organized in 1949 by The Federation of Trade Unions of Yugoslavia, ${ }^{24}$ or rather its Slovenian branch in Ljubljana, the event included seven folk dance ensembles operating within different trade unions (railway, engineering, construction, printing, commercial). Of the seven ensembles, three presented exclusively Slovenian dances, another three also presented Yugoslav dances, and one ensemble presented only a program of another republic.

The Yugoslav programme was also an informal condition ("entry ticket") for participating at the folk dance festivals abroad, since Slovenian ensembles primarily represented

22 In addition to Montenegro and Bosnia and Herzegovina, Slovenia was the only republic with no professional national ensemble. For more, see Kunej, "Leaders and Followers"; Petkovski, "Professional Folk Dance Ensembles in Eastern Europe".

23 Zveza sindikatov Jugoslavije, "Spored plesov in izvajalcev na tekmi folklornih plesnih skupin sindikalnih kulturno-umetniških društev in sindikalnih podružnic" (1949).

24 The first decade following World War II in particular was characterized by operation of folk dance ensembles within trade unions 
Yugoslavia. ${ }^{25}$ The ensembles in cities, which were larger, better organized, with a stronger financial (and political) background, generally also had greater ambitions to represent the country at the international festivals. However, presentations of the Yugoslav program by Slovenian ensembles abroad should not only be seen as a political act, but also as a pragmatic one, since the ensembles with diverse programmes were seen as more attractive and preferred at foreign festivals.

As a rule, the Yugoslav programme was mostly performed by ensembles in major cities with the largest numbers of migrants from other Yugoslav republics. Smaller, peripheral rural ensembles did not have such programmes due to several reasons: the artistic management relied more heavily on local tradition, the ensembles had ethnically uniform and smaller memberships, and they generally didn't tour abroad, so the Yugoslav programme was not necessary.

Following the political changes in 1991, the major Slovenian folk dance ensembles abandoned much of their (Yugoslav) programme, which led to a sort of folklore turn: "The previously marginalized ensembles that only performed Slovenian programme have, in terms of values, moved closer to larger urban ensembles than ever before" ${ }^{26}$. It should be added that the rise in importance of smaller local ensembles was influenced not only by political changes, in terms of redefinition of national borders and new dividing lines between "us" and "them", but also by new social and economic circumstances - the failures or privatization of many important companies, unreliable financing of amateur activities, and greater significance of local communities and financing of these activities through local community funds.

In 1991, the Yugoslav programme disappeared from the stage repertoire of all Slovenian folk dance ensembles. For example, in the 1980, the repertoire of folk dance ensemble Koleda from Velenje featured 4 Slovenian and 8 Yugoslav choreographies, whereas in 1996, the entire repertoire consisted of 11 different choreographies, all of which represented exclusively Slovenian dance tradition. Similarly, in 1980s, folk dance ensemble Tine Rožanc from Ljubljana had 4 Slovenian and 7 Yugoslav choreographies, whereas in 2018, their entire programme consists of 28 choreographies, presenting and reproducing Slovenian traditions. It is estimated that such ensembles "lost" one-half to two-thirds of their previous programme.

Until the ensembles consisted of dancers who had performed such programme on stage in the past, the programme was occasionally performed off stage, as part of regular exercises aimed at developing dance skills or just for fun. After 1991, in was not "politically correct" to perform this programme on stage, except in exceptional circumstances - on anniversaries, as part of a retrospective. On such occasion, it was (is) usually performed by former dancers rather than relevant active dancers. Therefore, the experience of performing Yugoslav programme on stage is reserved for the generations of dancers from 1945 to 1991 . This was another factor that contributed to the formation of minority folk dance ensembles.

25 When, in 1973, France Marolt Student Folk Dance Group toured in USA as the first Slovenian ensemble, they performed with one Slovenian choreography; the other four were part of the Yugoslav programme.

26 Bojan Knific, "Folkloriziranje plesnega izročila: prostorske, časovne in družbene razsežnosti ljudskih in folklornih plesov," Etnolog 20 (2010): 127-28 


\section{Emergence of minority folk dance ensembles and their organization}

During Yugoslav era, there were no minority folk dance ensembles in Slovenia (yet). Similarly, there was no formally organized groups or societies, in which ethnic groups from the former republics of Yugoslavia would meet and work, and in which minority folk dance ensembles operate today. The main reason for this was the state system, in which six socialist republics (Slovenia, Croatia, Serbia, Bosnia and Herzegovina, Montenegro, Macedonia) and two autonomous provinces (Vojvodina, Kosovo) were united into a federal state. ${ }^{27}$ Such arrangement ensured equal status of the people of Yugoslavia in all republics and provinces and was based on the principle of brotherhood and unity, which emphasized a "brotherly" relationship among peoples and nationalities and the equality of all citizens under socialism. The system was devised to resolve the complex international, cultural and religious relations in Yugoslavia. Many people from other republics used to live in Slovenia during the time of Yugoslavia, having migrated to Slovenia mainly for economic reasons. However, these migrations were considered as internal migrations within the country. Due to the federal system of the government, the principle of equality of all inhabitants, and the universal promotion of brotherhood and unity, there were no formal organizations of ethnic-based communities among the migrants. Namely, the state institutions oversaw the program of internationalization and cultural exchange between the republics and nationalities of the common state and organized numerous cultural exchanges and meetings. Furthermore, the state policy did not support the establishment of cultural societies on a national basis, and as a result, only some informal types of socializing existed among the members of ethnic groups, e.g. in the form of clubs. ${ }^{28}$

After the independence of Slovenia in 1991 and the breakup of Yugoslavia, the sociopolitical situation has changed, and with it the status of residents from other republics of Yugoslavia in Slovenia. The situation led to a "state of cultural isolation", ${ }^{29}$ where the relations and contacts between institutions, as well as between individual residents of the former republics were cut off, which was especially felt by migrants from the former Yugoslav republics. Their relation between "us" and "them" changed; despite the fact that they mostly acquired Slovenian citizenship and began living in the new Slovenian state, their status has changed from members of the previously common state to ethnic minority communities, which often felt the need to reinforce their ethnic identity, "to distinguishing the minority from the majority nation", ${ }^{30}$ and to cultivate relations with their nations of origin.

These changes let to the formation, in accordance with the Societies Act, of societies on ethnic (national) basis, which today represent the institutionalized form of migrant activities in Slovenia and organize various activities that enable their members to socialize and express their identity. Often, these societies began as informal activities and participation of the minority communities in humanitarian efforts in the early 1990s,

27 The official name of the country at the time was Socialist Federal Republic of Yugoslavia, abbreviated SFRY.

28 Cf. Ilija Dimitrievski et al., eds., 20 let uspešnega delovanja Zveze makedonskih kulturnih društev Slovenije: 1994-2014 (Ljubljana: Zveza makedonskih kulturnih društev Slovenije, 2014), 8.

29 Ibid., 11.

30 Bejtullahu, "Glasba in ples narodnih manjšin v Sloveniji," 161. 
when the war was still ongoing in some parts of the former Yugoslavia; migrants living in Slovenia organized humanitarian actions to help the inhabitants and relatives in their homeland, and provided care for refugees. As the situation in the Balkans improved, they focused their efforts on organizing social evenings, parties and events, as well as on the formal establishment of societies. ${ }^{31}$ These societies are engaged in different areas, with their main focus on cultural activities, which is usually reflected in the very names of the societies. ${ }^{32}$ Cultural and artistic activities thus represent a common and important task of many ethnic minority societies in Slovenia.

In Slovenia, cultural associations of member of other nationalities from the former common state began to form in 1992, but their number quickly increased in the mid1990s, following the end of the wars after the breakup of Yugoslavia. According to Vera Kržišnik-Bukić, there were 64 officially registered cultural societies, associations and federations of Albanians, Bosniaks, Montenegrins, Croatians, Macedonians and Serbs in mid-2004, and 70 in 2008. ${ }^{33}$ According to the 2014 estimate, "over 100 such societies" 34 were operating in Slovenia at that time. ${ }^{35}$

The increasing number of cultural associations of ethnic communities highlighted the need of these organization to integrate, work together and coordinate their activities, which was realized with the establishment of federations of cultural societies of the individual ethnic groups. ${ }^{36}$ These federations function as umbrella organizations, bringing together associations and highlighting their common goals, which most often include preserving national identity and nourishing traditions, culture and language, as well as active engagement in addressing social status and promoting the collective rights of members of ethnic communities.

The federations that linked the associations of individual ethnic communities also had certain common interests and goals, in particular facilitating the implementation of their programmes vis-à-vis the state and its institutions. As a result, they united to form the so-called EXYUMAK Coordination, or The Coordination of Federations and

31 Cf. Bejtullahu, "Glasba in ples narodnih manjšin v Sloveniji"; Glamočanin, "Organiziranje pripadnikov srbske skupnosti v kulturna društva v Sloveniji”; Marina Perić Kaselj et al., "Croatian Ethnic Associations in Slovenia: Historical Context and the Ethnic Situation," Dve domovini, 34 (2016): 105-15.

32 For example, the article on Croatian societies in Slovenia states that out of eleven societies united in the Association of Croatian Societies in Slovenia, no less than eight societies have the phrase "Croatian Cultural Society" in their name (Perić Kaselj et al., "Croatian Ethnic Associations in Slovenia," 109). List of the names of societies in other associations also show frequent occurrence of the terms such as "cultural society" or "cultural artistic society", and the names of some associations in themselves indicate that they are bringing together societies in the field of culture (e.g., Association of Macedonian Cultural Societies in Slovenia, Bosniak cultural association of Slovenia).

33 Vera Kržišnik-Bukić, "Narodnomanjšinsko vprašanje v Sloveniji po razpadu Jugoslavije: O družbeni upravičenosti vprašanja statusa narodnih manjšin Albancem, Bošnjakom, Črnogorcem, Hrvatom, Makedoncem in Srbom v Republiki Sloveniji s predlogi za urejanje njihovega narodnomanjšinskega položaja," Razprave in Gradivo 56-57 (2008): 130.

34 Dimitrievski et al., 20 let uspešnega delovanja Zveze makedonskih kulturnih društev Slovenije, 13.

35 An example of the rapid increase in the number of societies can also be seen in Milan Glamočanin's presentation of the organization of Serbian community into cultural societies, where he states that in 2003, "approximately 15 Serbian societies" were registered in Slovenia, and this number almost doubled in the next six years for a total of " 27 Serbian [registered] cultural societies" in 2009. Glamočanin, "Organiziranje pripadnikov srbske skupnosti v kulturna društva v Sloveniji," 124.

36 The Association of Macedonian Cultural Societies in Slovenia was founded in 1994, and according to their website, includes seven cultural societies. The Association of Serbian Societies of Slovenia was established in 1996; at the time of the establishment, it consisted of eight societies, which over the years increased to seventeen. The Bosnian Cultural Association of Slovenia was officially registered in 1997, and in 2014, consisted of nine member societies. The Alliance of Montenegro Associations of Slovenia was founded in 2009 - it first included two societies and was later joined by another one. Also active are The Association of Croatian Societies in Slovenia and The Association of Albanian Societies in Slovenia. 
Cultural Societies of Constituent Peoples and Nationalities of the Former Yugoslavia in The Republic of Slovenia, ${ }^{37}$ which in 2006 was formally registered as an association under the Societies Act as The Association of Cultural Societies of Constitutive Nations and Nationalities of the Former SFRY in Slovenia. The Coordination Agreement, signed by the federations of the Albanian, Bosniak, Croat, Macedonian, Serb, and later Montenegrin cultural societies, defined the purpose of the operation, highlighting the efforts to recognize the status of national minorities to these ethnic communities. ${ }^{38}$ As noted by Vera Kržišnik-Bukić:

It [The Association of Cultural Societies] is in fact an informal and, in light of the circumstances, a common political representative body of the respective population in the Republic of Slovenia. It is a body with a dual, complementary role, which internally articulates and synthesizes the common interests of the represented entities as a whole, and externally establishes contacts with state bodies, political parties, other entities in Slovenia and abroad, and with the media - in short, with all those who are in any way willing and able to contribute to, or at least understand, the goals of the Association of Societies. ${ }^{39}$

The number of minority folk dance ensembles which emerged in Slovenia in the changed social and political situation after the breakup of Yugoslavia soon increased, and their activities became organized. The institutional framework in which they operate today as part of cultural societies, along with their integration into federations of individual national communities and into the umbrella organization, The Association of Cultural Societies of Constitutive Nations and Nationalities of the Former SFRY in Slovenia, enables them to establish connections and cooperate within associations, and is indicative of the broader efforts and goals which go beyond the cultural and artistic activities of the cultural societies. Through their representatives and associations, the societies thus function as a "socially and politically organized body", ${ }^{40}$ actively participating in the socio-political developments in Slovenia.

\section{Activities of folk dance sections within ethnic cultural societies}

Alma Bejtullahu ${ }^{41}$ notes that in 2016, there were about 70 groups in Slovenia that were involved in music and dance representation within cultural societies of ethnic communities, adding that in such societies, music and dance have "a special place, due to their nationally representative meaning". ${ }^{42}$ She particularly emphasizes the various forms of representation of folk music and folk dance tradition, often realized in the form of folklore ensembles, which in the central, eastern and southeastern parts of Europe also

37 For more, see: Kržišnik-Bukić, "Narodnomanjšinsko vprašanje v Sloveniji po razpadu Jugoslavije."

38 Cf. Dimitrievski et al., 20 let uspešnega delovanja zveze makedonskih kulturnih društev Slovenije, 13.

39 Kržišnik-Bukić, "Narodnomanjšinsko vprašanje v Sloveniji po razpadu Jugoslavije," 131.

40 Bejtullahu, "Glasba in ples narodnih manjšin v Sloveniji," 160.

41 Ibid.

42 Ibid., 161. 
emerged on the basis of ethnomusicological and folkloristic research approaches. Similarly, Glamočanin states that based on the analysis of the activities of 27 cultural societies of the Serbian community in Slovenia, the folklore activity is the most widespread and developed activity of Serbian cultural societies, ${ }^{43}$ with folklore sections organized in as many as 16 societies:

No other section (drama, literary, sports, etc.) is so widely represented. Among the 16 associations, there are even a few where the folklore section is the only one active and was the reason for the founding of the cultural society. [...] Folklore activity is the most widespread both in terms of active members of sections, the folklore events organized by the societies, and by the number of visitors. ${ }^{44}$

The multiplicity and prevalence of the folklore activity within societies is also evident from the number of applications submitted for the tender for the co-financing (ETN projects under the Public Fund for Cultural Activities). Although several activities are financially supported under the call (folklore, literature, theatre, music, dance, film, fine arts, and interdisciplinary projects), the minority ethnic associations are predominantly applying in the field of "folklore activities", which again proves to be the most important area of cultural production for minority communities, and is their most representative activity. The predominant focus on "folklore activities" is also apparent from the fact that as a rule, music projects are always linked to traditions and are therefore classified as "folklore" rather than "music". 45

In addition, folk dance ensembles are the most active sections of societies. For example, as noted by the Macedonian Cultural Society of St. Cyril and Methodius from Kranj: "The folklore section has been the most active section ever since the founding of the society, and remains to this day. From the earliest beginnings until today, multiple generations of dancers have exchanged." 46

Furthermore, the activities of folk dance ensembles are of broader significance for the minority communities. The analysis of the Serbian societies highlighted the following:

Regarding the activities of the folklore sections within Serbian cultural societies, it should be noted that the rehearsals and meetings of the members are held in Serbian language, that the members use non-translated names and descriptions of dances, poems and names of particular customs or beliefs. At the same time, in connecting individual dances to their areas of origin, the members of sections also learn about the geographical areas of Serbia and the territories where Serbs used to live (in Bosnia, Croatia, Macedonia, Romania, Bulgaria, Hungary). In addition to geographical information, the member gain knowledge of historical facts, of the settlement

43 Here he cites the example of the Cultural Society Brdo from Kranj, where the folklore section of the society consists of 110 members, drama section of 11 members, vocal section of 7 members, alpine section of 15 members, and sports and chess section of 20 members. Glamočanin, "Organiziranje pripadnikov srbske skupnosti v kulturna društva v Sloveniji," 126.

44 Glamočanin, "Organiziranje pripadnikov srbske skupnosti v kulturna društva v Sloveniji," 127.

45 See more: Urša Šivic, "History of Public Call for Funding in the Field of the Cultural Activities of Ethnic Minority Communities and Immigrants," Muzikološki zbornik 55, no. 2 (2019): 133-153.

46 Dimitrievski et al., 20 let uspešnega delovanja Zveze makedonskih kulturnih društev Slovenije, 45. 
of Serbs in these areas, and of their cultural development. Their acquaintance with the past clothing culture, the history of the development of traditional instruments and more contributes to the dissemination of knowledge about a particular nation. In addition, folklore events build the knowledge of the national identity and raise awareness of their roots. Dressing in folk costumes, most of which are reconstructions the "national costumes", in itself gives impression, at least during the performance, of a different, changed identity. ${ }^{47}$

With their prevalence, activity and numbers, folk dance ensembles are the most recognizable and representative sections of many ethnic cultural societies, representing the "showpiece" of a society. ${ }^{48}$ Furthermore, it has repeatedly been shown that it is through the activities of the folk dance ensembles, with mostly young active membership, that societies succeeded in achieving the fundamental goal of ethnic associations: to address and engage the younger generation. ${ }^{49}$

\section{Institutionalization and regulation of activities of minority folk dance ensembles}

Experts in the field of minority folk dance ensembles emphasize the great importance of presenting the traditions on stage, especially for the younger generation who are motivated by socializing, performing, evaluating and competing. Initially, minority folk dance ensembles mainly performed at local levels and in art events organized by members of individual cultural communities. As their numbers and activities increased, ensembles began to become more involved in various cultural events in Slovenia. Soon, the desire and need emerged for a more organized representation of minority folk dance ensembles, closer cooperation, encouragement of activities, and care for quality growth. In 1999, for example, Macedonian Cultural Society of St. Cyril and Methodius from Kranj organized its "First ethno-folk meeting" of minority folk dance ensembles. The event named "Ethno-Folk Festival" soon became traditional, it has survived to this day, and according to organizers, is "one of the largest folklore events organized by an amateur cultural association in Slovenia". ${ }^{50}$ Throughout the years, the purpose of the event has remained the same: "to unite and represent the Macedonian, Slovenian, Serbian, Croatian, Bosniak and Montenegrin folklore traditions in one place, and to remain open to other traditions". ${ }^{1}$

Similarly, Serbian folk dance ensembles also began presenting their activities in Slovenia in an organized manner. Due to the large numbers and great activity of

47 Glamočanin, "Organiziranje pripadnikov srbske skupnosti v kulturna društva v Sloveniji," 127.

48 Cf. "Folklorna sekcija," Kulturno i sportsko društvo SANDŽAK u Sloveniji, http://www.glas-sandzaka.si/nase-sekcije/folklornasekcija.

49 For example, the analysis of the activities of Croatian ethnic societies in Slovenia emphasizes the fact that the main purpose of establishing most societies is "the need to transfer ethnic culture to one's successor, and to gain more young members of the community", which is seen as the only possibility for the ethnic community to survive. Perić Kaselj et al., "Croatian Ethnic Associations in Slovenia," 110.

50 Dimitrievski et al., 20 let uspešnega delovanja Zveze makedonskih kulturnih društev Slovenije, 30.

51 See "17. Etno-folk festival," Sokultura, http://sokultura.si/wp/aktualno/17-etno-folk-festival/. 
Serbian folk dance ensembles, The Serbian Community Association, based in Ljubljana, began organizing the Meeting of Serbian Folk Dance Ensembles of Slovenia in 2001, which was then held annually over the next five years. According to Jovan Mijalković, the chief organizer of these meetings within The Serbian Community Association, the first meetings had more of an exhibition character, with no expert evaluations, mainly for the purpose of presenting the activities of individual ensembles and socializing; the quality of the program was also relatively low. ${ }^{52}$ However, the report from the $4^{\text {th }}$ meeting in 2004 already mentions higher quality of stage sets and dance technique of the performers compared to previous years. ${ }^{53}$ At the same time, Mijalković points out in his report the lack of personal knowledge, skills and creativity of some dance choreographers, who often use choreographies or parts of choreographies of other ensembles without permission, and advises the young to educate themselves at seminars in Serbia and Slovenia.

Increasingly, minority folk dance ensembles also became involved in an organized system of meetings, evaluations and educations, used by the Public Fund for Cultural Activities (JSKD) to promote and guide the activities of folk dance ensembles in Slovenia. Until 2008, minority ensembles have been presenting themselves at local and regional meetings, together with Slovenian folk dance ensembles. ${ }^{54}$ Their performance was evaluated by an expert evaluator, who supervised both Slovenian and non-Slovenian ensembles and guided them with advice. During this period, the most suitable people for the position of expert evaluator at the meetings where minority ensembles participated were former artistic leaders of established Slovenian folk dance ensembles with the Yugoslav programme, who thus had a relatively good knowledge of the dance tradition of other republics of Yugoslavia. ${ }^{55}$

Due to the increasing number of minority folk dance ensembles attending the meetings organized by JSKD, they decided in 2008 to organize special meeting with only minority folk dance ensembles in Slovenia. ${ }^{56}$ Only one meeting for the whole Slovenia was organized that year and was held in the Gorenjska region, where most of such ensembles were active. There were two Macedonian, two Serbian and one Bosniak folk dance ensemble participating, all of them based in the Gorenjska region (Kranj, Jesenice). The 2009 meeting saw similar participants and was also organized only once, again in the same region.

In 2010, JSKD wanted to take a more systematic and comprehensive approach to organizing minority folk dance ensemble meetings. A letter was sent to all minority cultural societies at the end of 2009, containing a notice on the organization of meetings and an invitation to participate:

52 Jovan Mijalković, in discussion with the author, October 23, 2017

53 Jovan Mijalković, “4. Srečanje Srbskih Folklornih Skupin Iz Slovenije," Folklornik 1 (2005): 56.

54 For example, folk dance ensemble Moravac, which operated as a folklore section of The Serbian Community Association from Ljubljana, has participated at the regional meetings of the folklore ensembles in it designated area every year since 2002.

55 Cf. Jovan Mijalković, in discussion with the author, October 23, 2017; Bojan Knific, in discussion with the author, September 14, 2018.

56 Cf. Vesna Bajić Stojiljković, "Ples nas združuje: Srečanja folklornih skupin manjšinskih etničnih skupnosti", Folklornik 6 (2010): 148 
In the 2009/2010 season, the Public Fund for Cultural Activities, in cooperation with cultural societies, organizes meetings of folk dance ensembles (children, youth, adults, veterans, etc.) which are active in Slovenia and recreate dance and music traditions of other nations and nationalities (Croatian, Serbian, Bosniak, Macedonian, Albanian, Montenegrin, and other). We are preparing four calls for proposals in order to have as many ensembles as possible presenting themselves at the meeting [...] with this letter, we want to inform you about the meetings so you can prepare for them on time. ${ }^{57}$

Following the model of the meetings of Slovenian folk dance ensembles, the meetings of minority ensembles were organized in the form of regional meetings, which divided the territory of Slovenia into four units, slightly fewer than in the case of Slovenian folk dance ensembles. The letter also states that the meetings are aimed at "getting to know, monitoring and promoting the quality of the associations and ensembles, as well as keeping records of the societies active in the field of recreation of the cultural heritage of other nations and nationalities in Slovenia". ${ }^{58}$

The call by JSKD and a different organization of meetings clearly contributed to the increased participation of minority folk dance ensembles at the meetings. For example, the 2010 meetings saw the participation of 14 minority folk dance ensembles: 8 Serbian, 2 Macedonian, 2 Bosniak, and 2 Croatian. Vesna Bajić Stojiljković, who has been performing the role of expert evaluator at these meetings since 2008, published a report in 2010 titled "The meetings of folk dance ensembles of minority ethnic communities", 59 where she emphasized the fact that, due to various reasons, the participation of minority folk ensembles at the meetings was quite low, since the number of such ensembles in Slovenia is much higher than the number of participating ensembles at the meetings. As an exception, she mentioned Serbian ensembles which had begun participating at the meetings in large numbers. In conclusion, she describes the expert consultations after the performances as being very helpful for the participants, due to the fact that the ensembles - in addition to opinions, advice and guidance of the expert evaluators - get the opportunity to get to know each other, talk, and exchange views and experiences.

The practice of organizing special meetings for minority folk dance ensembles in the form of four regional meetings continued in the following years, with the number of participants increasing every year. In the 2011/2012 season, for example, a total of 25 ensembles, including children ensembles, participated at the meetings. ${ }^{60}$ The increasing trend of the number of participating ensembles, the diversity of the programme, and the increase in the number of children ensembles can also be seen in the report by Vesna Bajić Stojiljković, who was the expert evaluator at the meetings in the following, 2012/2013 season. ${ }^{61}$

57 JSKD, "Dopis kulturnim društvom," November 15, 2009.

58 Ibid.

59 Bajić Stojiljković, "Ples nas združuje".

60 Jovan Mijalković, "Poročilo o regijskih srečanjih folklornih skupin manjšinskih etničnih skupnosti - 2011/2012," Folklornik 8 (2012): 130

61 Vesna Bajić Stojiljković, "Aktivnosti folklornih, pevskih in godčevskih skupin manjšinskih etničnih skupnosti v sezoni 2012/13," Folklornik 9 (2013): 133-34. 
However, the increase in the number and activities of the minority folk dance ensembles actively involved in the organized JSKD system of meetings, evaluations and guidance of amateur cultural activities in Slovenia, was not merely a reflection of the needs and desires for a more organized representation of the minority folk dance ensembles, for a closer cooperation, encouragement of activities, and care for quality growth. By integrating into the JSKD framework, the ensembles and associations of minority communities could apply for financial support. This is evidenced from the aforementioned letter, sent in 2009 by JSKD to minority cultural societies, inviting them to participate at the meetings:

In addition, by attending the meetings, you will gain a unified and direct insight into the functioning of the societies, which is also important in other aspects (e.g., with tenders by JSKD, Ministry of Culture, municipalities, and the like). [...] At the same time, we would like to use this opportunity to inform you that for the first time this year, the Public Call for Selection of Cultural Projects in the Field of Different Minority Ethnic Communities and Immigrants in the Republic of Slovenia will be made through the Public Fund for Cultural Activities of the Republic of Slovenia (JSKD). [...] We invite you to submit quality projects with a clear concept. ${ }^{62}$

The financial support by Slovenian institutions is very important for the functioning of minority folk dance ensembles, which is often emphasized; some ethnic cultural societies have even been formally institutionalized in the form of cultural societies, mainly to facilitate the acquisition of funds through tenders of state institutions. ${ }^{63}$ With regard to the financing of societies within the Association of Macedonian Cultural Societies in Slovenia, for example, they noted that one of the key activities of the Association was to secure the financing of their societies, and added that the largest share of the funds received by their societies came from the current JSKD and the Ministry of Culture Department for Minority and Immigration Issues ${ }^{64}$ However, as the number of minority ethnic society increased, the number of applicants for funding from the aforementioned sources increased, while the amount of available funds remained the same. Due to the increase in the number of applicants and applications submitted, the criteria for awarding funding in the tenders were also raised. One of the important criteria introduced by JSKD for the financing of project in the field of "folklore activity" was participation at the regional meetings, while a good evaluation of the performance increased the possibility of financial support. ${ }^{65}$ This further increased the importance of participating at the meetings organized by JSKD, as well as of the evaluation of the performances by expert evaluators. In turn, such professional monitoring, guidance and financing also influenced the repertoire of the minority folk ensembles, the way they are presenting dance and music traditions, and the functioning of such ensembles.

62 JSKD, "Dopis kulturnim društvom," November 15, 2009.

63 Cf. Bejtullahu, "Glasba in ples narodnih manjšin v Sloveniji; Glamočanin, "Organiziranje pripadnikov srbske skupnosti v kulturna društva v Sloveniji"; Jovan Mijalković, in discussion with the author, October 23, 2017; Bojan Knific, in discussion with the author, September 14, 2018.

64 Ilija Dimitrievski et al., 20 let uspešnega delovanja Zveze makedonskih kulturnih društev Slovenije, 28.

65 Cf. Bejtullahu, "Glasba in ples narodnih manjšin v Sloveniji," 173. 


\section{Conclusion}

There are several causes for the emergence of minority folk dance ensembles in Slovenia after independence. The breakup of Yugoslavia led to significant changes in the functioning of Slovenian folk dance ensembles, with the latter completely abandoning the Yugoslav programme and focusing exclusively on presenting Slovenian traditions. The largest share of the Yugoslav programme was performed by folk dance ensembles in major cities, with the largest number of migrants from other Yugoslav republics, who were also members of such ensembles. But above all, the principle of brotherhood and unity between the peoples of the former Yugoslavia has been abandoned due to political changes following independence, and the once vibrant intercultural exchange between the republics has died down. A new relation between "us" and "them" was formed, uniting many migrants from the former republics of Yugoslavia in ethnic minority communities, which felt the need to strengthen their ethnic and cultural identity and to establish connections with their nations of origin.

Minority folk dance ensembles have proven to be a very suitable form for realizing the goal of minority ethnic communities, which have institutionalized their activities in the form of cultural societies. The latter, along with the Associations of Cultural Societies were established primarily for the purpose of preserving national identities and nourishing the traditions and culture of the ethnic minority communities. ${ }^{66}$ In the new socio-political context, the orientation of the folk dance ensembles - which in the countries of Southeast and Eastern Europe was closely linked to national cultural policy, and in the former Yugoslavia also to the political ideology of building a common Yugoslav identity based on brotherhood among nations - has been transferred, in a modified form, to a minority folk dance ensembles. These have often become the most widespread, active, and representative activity of the societies, closely linked to ethnic identifications. Due to their attractive nature of activity, which combines music, dance, and tradition and is being realized through socializing, performing, meetings and competitions, folk dance ensembles include many actively involved young people. The inclusion in societies of the younger generation, and thus passing on the culture to the next generations, is one of the most important goals of societies, as it is the only way for the long-term survival of the ethnic communities.

Minority folk dance ensembles are part of the cultural policy in Slovenia. They are not looking to assimilate, but rather to integrate, and their goal is to obtain equal status to Slovenian folk dance ensembles. On the other hand, Slovenian ensembles are also looking for the equal treatment to minority ensembles, especially in terms of financial support. ${ }^{67}$ This was the reason for the transfer of the funding for ethnic

66 Cf. "O SSDS," Zveza srbskih društev Slovenije, http://www.ssds.si/?page_id=29; "O nas - Bošnjaška kulturna zveza Slovenije," Sokultura, http://sokultura.si/wp/kdo-smo/o-nas/; "Zveza Črnogorskih Društev Slovenije," https://zvezacds.weebly.com/ about.html.

67 All Slovenian folk dance ensembles operate in the amateur sphere, by which we mean, above all, unpaid artistic creating and re-creating (performing), since there is no professional who could engage in this activity (choreography, artistic leadership, expert advice) as their main source of income. In the case of minority folk dance ensembles, however, there are signs of professionalization of the activities, despite the significantly smaller number of ensembles, especially when activities are supported by their country of origin and are not only tied to the Slovenian territory but also but to global ethnic networks. 
societies from the Ministry of Culture to JSKD, which takes care of the entire amateur culture in Slovenia through calls for proposals (ETN and a call for folklore activity) and professional guidance.

The activities of minority folk dance ensembles do not depend solely on the Slovenian cultural policy, but largely also on the interest and support of their "countries of origin" ${ }^{6}$ with their own financial, professional and moral support. Therefore, all minority ensembles cannot be considered as a homogenous entity; each one deserves individual attention. In Slovenia, too, minority folk dance ensembles are at the same time "part of their respective global diasporic networks, with each one being a node whose inspirational focus is the sending society", ${ }^{69}$ as noted by J. Mollenhauer for Australia and its Irish and Croatian folk dance ensembles.

Countries of origin can use ethno-identity dance for purposes of valorizing ethnicity and the nation. ${ }^{70}$ Based on the presented activities of minority folk dance ensembles and the analysis of their involvement in the organized amateur culture in Slovenia, the top-down perspective shows that the goal of such ensembles in Slovenia is dancing for ethnic roots, but also the desire to enrich the cultural space in the new country and to integrate into the society in which they live. Janette Mollenhauer notes that dance takes on a new role in diaspora: "It retains its salience to the cultural identity formation of the dancers, but its role changes from being a normative practice to being an indicator of difference ...". ${ }^{71}$ Wrazen's statement, "in order to present this past as a way to better define their present", ${ }^{72}$ also applies to minority folk dance ensembles in Slovenia, especially bearing in mind that music and dance, as forms of non-verbal communication, are (or can be) a marker of ethnic identity which remains long after the language disappears.

\section{Bibliography}

Aubert, Laurent. The Music of the Other: New Challenges for Ethnomusicology in a Global Age. Translated by Carla Ribeiro. Aldershot, England; Burlington, VT: Ashgate, 2007.

Bajić Stojiljković, Vesna. "Aktivnosti folklornih, pevskih in godčevskih skupin manjšinskih etničnih skupnosti v sezoni 2012/13.” Folklornik 9 (2013): 133-134.

. "Ples nas združuje: Srečanja folklornih skupin manjšinskih etničnih skupnosti." Folklornik 6 (2010): 148-151.

Bajić, Vesna. "Folklorna dejavnost v Srbiji." Folklornik 6 (2003): 88-89.

Bejtullahu, Alma. "Glasba in ples narodnih manjšin v Sloveniji: Nacionalna identiteta, eksotika, past stroke [Music and Dance of Ethnic Minorities in Slovenia: National Identity, Exoticism, and the Pitfalls of Ethnomusicology]." Traditiones 45, no. 2 (2016): 159-176. doi: 10.3986/Traditio2016450210.

68 The term country of origin/source country is used in minority cultural societies, despite the fact that many members of the minority ethnic folk ensembles were born in Slovenia. In using the term, we are aware of its "inadequacy" when understood in a literal sense.

69 Mollenhauer, "Dance in Diaspora," 1.

70 Cf. Shay, Ethno Identity Dance for Sex, Fun and Profit, 11.

71 Mollenhauer, "Dance in Diaspora," 1.

72 Wrazen, "Diasporic Experiences," 48. 
Dimitrievski, Ilija, et al., eds. 20 let uspešnega delovanja Zveze makedonskih kulturnih društev Slovenije: 1994-2014. Ljubljana: Zveza makedonskih kulturnih društev Slovenije, http://www.mkd-kim.si/monografija/zveza/slo.pdf.

Glamočanin, Milan. "Organiziranje pripadnikov srbske skupnosti v kulturna društva v Sloveniji." Folklornik 6 (2010): 124-127.

Herzog, Philipp. "National in Form and Socialist in Content' or Rather 'Socialist in Form and National in Content'?: The 'Amateur Art System' and the Cultivation of 'Folk Art' in Soviet Estonia.” Narodna Umjetnost 47, no. 1 (2010): 115-140.

Ilieva, Anna. "Bulgarian Folk Dance during the Socialist Era, 1944-1989." Yearbook for Traditional Music 33 (2001): 123-126. doi: 10.2307/1519636.

JSKD. "Dopis kulturnim društvom." November 15, 2009.

Kapper, Sille. "Post-Colonial Folk Dancing: Reflections on the Impact of Stage Folk Dance Style on Traditional Folk Dance Variation in Soviet and Post-Soviet Estonia." Journal of Baltic Studies 47, no. 1 (2016): 93-111. doi: 10.1080/01629778.2015.1103515.

Knific, Bojan. "Folkloriziranje plesnega izročila: Prostorske, časovne in družbene razsežnosti ljudskih in folklornih plesov [Folklorisation of the Dance Heritage: Spatial, Temporal, and Social Dimensions of Folk and Folkloric Dances].” Etnolog 20 (2010): 115-134.

—_. "Interpretiranje plesnega izročila: Lokalno, nacionalno in nadnacionalno [Interpreting Folk Dance Heritage: Local, National and Transnational Level].” Traditiones 42, no. 1 (2013): 125-142. doi: 10.3986/Traditio2013420107.

Kržišnik-Bukić, Vera. "Narodnomanjšinsko vprašanje v Sloveniji po razpadu Jugoslavije: O družbeni upravičenosti vprašanja statusa narodnih manjšin Albancem, Bošnjakom, Črnogorcem, Hrvatom, Makedoncem in Srbom v Republiki Sloveniji s Predlogi za urejanje njihovega narodnomanjšinskega položaja [National-minority Question in Slovenia after the Breakdown of Yugoslavia: On the Justification of the Acknowledgment of the National Minority Status for the Albanians, Bosniacs, Croats, Macedonians, Montenegrins and Serbs in the Republic of Slovenia, Along With the Model Managing Proposals]." Razprave in Gradivo 56-57 (2008): 120-156.

Kunej, Rebeka. "Leaders and Followers: Artistic Leaderships and Stage Presentations of Folk Dances in a Slovenian Folklore Ensemble." In Folklore Revival Movements in Europe Post 1950: Shifting Contexts and Perspectives, edited by Daniela Stavělová, and Theresa Jill Buckland. Prague: Institute of Ethnology of the Czech Academy of Sciences, 251-271.

Kunej, Rebeka. "From Kolo to Polka: Folk Dance Ensembles in Slovenia after 1991." In Music and Dance of the Slavic World: Tradition and Transitions, edited by Sonja Zdravkova Djeparoska. Skopje: Faculty of Music, forthcoming.

Kunej, Rebeka, and Drago Kunej. "Folklorna skupina v diaspori: Soočanje tradicije in ustvarjalnosti v Ameriki [A Folklore Ensemble in the Diaspora: Tradition Confronting Creativity in America].” Etnolog 26 (2016): 49-64.

Mijalković, Jovan. “4. Srečanje srbskih folklornih skupin iz Slovenije.” Folklornik 1 (2005): 56.

—_. "Poročilo o regijskih srečanjih folklornih skupin manjšinskih etničnih skupnosti - 2011/2012." Folklornik 8 (2012): 130. 
Mollenhauer, Jeanette. "Dance in Diaspora: The Politics of Practice." Paper presented at Power, Politics and the Dancing Body; Dance Research Forum Ireland Conference, Limerick, June 2018: 1-8. https://www.researchgate.net/ publication/330426200_DANCE_IN_DIASPORA_THE_POLITICS_OF_PRACTICE.

_- . "Dancing Transnationally: Croatian Immigrants in Sydney, Australia." Narodna Umjetnost 561 (2019): 129-147. doi: 10.15176/vol56no108.

Nahachewsky, Andriy. Ukrainian Dance: A Cross-Cultural Approach. Jefferson, N.C: McFarland \& Co, 2012.

Pavlicová, Martina, and Lucie Uhlíková. "Folklore Movement and Its Function in the Totalitarian Society (on an Example of the Czech Republic in the 2nd Half of the $20^{\text {th }}$ Century)." Národopisná Revue 23, no. 5 (2013): 31-41.

Perić Kaselj, Marina, Aleksandar Vukić, and Jelena Zlatković Winter. "Croatian Ethnic Associations in Slovenia: Historical Context and the Ethnic Situation." Dve Domovini, no. 34 (2016): 105-115.

Petkovski, Filip. "Professional Folk Dance Ensembles in Eastern Europe and the Presentation of Folk Dance on Stage." In Music and Dance in Southern Europe: New Scopes of Research and Action. Fourth Symposium of the ICTM Study Group on Music and Dance in Southeastern Europe, edited by Liz Mellish, Nick Green and Mirjana Zakić,173-178. Belgrade: ICTM Study Group on Music and Dance in Southeastern Europe; Faculty of Music, University of Belgrade, 2016.

Shay, Anthony. Ethno Identity Dance for Sex, Fun and Profit: Staging Popular Dances around the World. London: Palgrave Macmillan, 2016.

Stavělová, Daniela, and Theresa Jill Buckland, eds. Folklore Revival Movements in Europe Post 1950: Shifting Contexts and Perspectives. Prague: Institute of Ethnology of the Czech Academy of Sciences, 2018.

Šivic, Urša. "History of Public Call for Funding in the Field of the Cultural Activities of Ethnic Minority Communities and Immigrants." Muzikološki zbornik 55, no. 2 (2019): 133-153.

Wong, Sau-ling C. "Dancing in the Diaspora: Cultural Long-Distance Nationalism and the Staging of Chineseness by San Francisco"s Chinese Folk Dance Association." Journal of Transnational American Studies 2, no. 1 (2010): Article 15. http://escholarship. org/uc/item/50k6k78p.

Wrazen, Louise. "Diasporic Experiences: Mediating Time, Memory and Identity in Górale Performance." Musicultures 32 (2005): 34-51.

Zájedová, Iivi, and Eha Rüütel. "Folk Dance Practice and Transmission of the Folk Dance Tradition by Expatriate Estonians in Sweden and Germany." Český Lid 101, no. 1 (2014): 57-76.

___. "National Cultural Hobby Activities of Estonians in Exile and Their Role as a Means of Perserving Estonianism." Ethnologia Actualis Slovaca 9 (2009): 97-109.

Zveza sindikatov Jugoslavije. Spored plesov in izvajalcev na tekmi folklornih plesnih skupin sindikalnih kulturno-umetniških društev in sindikalnih podružnic. [flyer], 1949. 


\section{POVZETEK}

Članek obravnava pojav in delovanje folklornih skupin etničnih manjšinskih skupnosti, ki so se v Sloveniji izoblikovale z razpadom Jugoslavije: albanske, bošnjaške, črnogorske, hrvaške, makedonske in srbske folklorne skupine. Pri tem se osredotoča na analizo okoliščin, ki so pripomogle k nastanku t. i. manjšinskih folklornih skupin in poskuša odgovoriti na vprašanja, zakaj se pojavijo takšne folklorne skupine šele po osamosvojitvi Slovenije, kakšni so bili začetki njihovega delovanja ter kako so se sčasoma organizirale, institucionalizirale in vključile v sistem delovanja ljubiteljske kulture v Sloveniji. Pojavu manjšinskih folklornih skupin v Sloveniji po letu 1991 je botrovalo več vzrokov. Po razpadu Jugoslavije je prišlo do bistvenih sprememb v delovanju folklornih skupin v Sloveniji, saj so povsem opustile predstavljanje programa iz drugih jugoslovanskih republik in se usmerile zgolj na prikaz slovenskega izročila. Predvsem pa se je zaradi političnih sprememb opustilo načelo bratstva in enotnosti ter načelo enakosti prebivalcev vseh republik nekdanje Jugoslavije, zamrla je tudi nekdaj živahna medkulturna izmenjava med republikami. Na novo se je oblikoval odnos mi-drugi, ki je priseljence iz nekdanjih republik Jugoslavije povezal v etnične manjšinske skupnosti, ki so čutile potrebo po krepitvi svoje etnične in kulturne identitete in potrebo po povezovanju z matičnimi narodi; svoje aktivnosti so pogosto institucionalizirale v obliki kulturnih društev. Folklorne skupine, ki so delovale v okviru kulturnih društev, so velikokrat postale najbolj aktivna, množična in reprezentativna dejavnost društev, tesno povezana z etnoidentitetnimi prizadevanji. Zaradi svoje atraktivne narave delovanja, ki združuje glasbo, ples in tradicijo ter se uresničuje na podlagi medsebojnega druženja, nastopanja, srečevanja in tekmovanja, je $\mathrm{v}$ folklorne skupine aktivno vključenih veliko mladih; njihovo vključevanje $\mathrm{v}$ društva in $\mathrm{s}$ tem posredovanje kulture naslednjim rodovom pa je eden najpomembnejših ciljev društev, saj lahko le tako etnične skupnosti dolgoročno preživijo.

V želji po institucionalizaciji, lažjemu pridobivanju finančnih sredstev na razpisih državnih ustanov in prizadevanju biti del slovenske kulture, so se manjšinske folklorne skupine vedno bolj vključevale tudi v organiziran sistem srečanj, evalvacij in izobraževanj, s katerimi JSKD vzpodbuja in usmerja delovanje folklornih skupin na Slovenskem. To je delno vplivalo na repertoar, na način predstavljanja plesnega in glasbenega izročila ter delovanje tovrstnih skupin, pri čemer pa si etnične manjšinske skupnosti ne želijo asimilacije ampak integracijo v slovenski kulturni prostor. 